\title{
PROFIL BISNIS STARTUP MAKANAN INSTAN MENGGUNAKAN BUSINESS MODEL CANVAS (BMC) (Studi Kasus Neng Daysi di Jatinangor Sumedang Jawa Barat)
}

\author{
BELINDA DWI ASTUTI ${ }^{1 *}$,TRISNA INSAN NOOR ${ }^{1}$ \\ ${ }^{1}$ Fakultas Pertanian, Universitas Padjadjaran \\ *Email: belindadwia@gmail.com
}

\begin{abstract}
ABSTRAK
Bisnis Startup saat ini dituntut untuk terus berkembang sehingga membuat bisnis Neng Daysi harus mampu mengoptimalkan bisnis menjadi lebih baik. Neng Daysi merupakan produk inovasi pangan fungsional yang lahir sebagai upaya dalam meningkatkan kualitas kesehatan masyarakat. Produk ini mengkombinasikan ekstrak tanaman bawang dayak dan beras sehingga mampu mengoptimalkan fungsi nasi sebagai makanan pokok. Penelitian ini menggunakan metode pendekatan Business Model Canvas (BMC). Berdasarkan hasil penelitian pada bisnis Neng Daysi menggunakan model bisnis kanvas sudah menunjukan kegiatan bisnis yang komprehensif terlihat dari setiap elemen-elemen blok yang tersedia sudah menjabarkan kegiatan bisnis secara detail. Sehingga dari hasil kesimpulan menunjukkan bahwa strategi dengan Business Model Canvas dapat secara efektif dan efisien dalam penentuan strategi bisnis Startup.
\end{abstract}

Kata Kunci : Business Model Canvas,Pangan Fungsional, Nasi Herbal

\begin{abstract}
Startup's business is currently demanded to continue to grow so that the Neng Daysi business must be able to optimize the business for the better. Neng Daysi is a functional food innovation product that was born as an effort to improve the quality of public health. This product combines dayak onion extract and rice so that it can optimize the function of rice as a staple food. This study uses the Business Model Canvas (BMC) approach. Based on the results of research on Neng Daysi's business using the canvas business model, it has already been shown that comprehensive business activities can be seen from each of the block elements available that has detailed business activities. So that the conclusion shows that the strategy with Business Model Canvas can be effective and efficient in determining the Startup business strategy.
\end{abstract}

Keywords: Business Model Canvas, Functional Food, Herbal Rice

\section{PENDAHULUAN}

\section{Latar Belakang}

Menurut Data Statistik dan Hasil

Survey Ekonomi Kreatif tahun 2017,

Produk Domestik Bruto (PDB) ekonomi

kreatif tercipta pada tahun 2015 sebesar 852,24 triliun rupiah,tercatat tumbuh sebesar 4,38 persen dan memberikan kontribusi sebesar 7,38 persen terhadap total perekonomian nasional. Ekonomi kreatif ini menyerap sekitar 16 juta total tenaga kerja pada tahun 2015. Dari 15 subsektor ekonomi kreatif yang dikembangkan, tiga diantaranya tercatat berkontribusi paling besar terhadap PDB yaitu sektor kuliner sebesar Rp.355,198 triliun atau 41,69 persen, Hal ini menunjukkan bahwa UMKM,terutama subsektor kuliner, memiliki posisi penting dalam kontribusi perekonomian nasional 
Neng Daysi merupakan usaha startup yang memproduksi produk nasi herbal instan sejak tahun 2018. Neng Daysi adalah sebuah produk inovatif dengan menggabungan beras dan ekstrak bawang dayak. Pemanfaatan tanaman bawang dayak dalam produk adalah sebagai pangan fungsional kaya akan manfaat yang dimana ekstrak tanaman bawang dayak disuntikan kedalam nasi yang telah diolah, lalu dilakukan proses penarikan kadar air menggunakan teknologi sehingga Neng Daysi menjadi produk pangan fungsional yang praktis. Produk Neng Daysi diharapkan dapat menjadi upaya pemecahan masalah akan tingginya angka diabetes dan tingginya konsumsi nasi putih. Berdasarkan data Riset Kesehatan Dasar (Riskesdas) pada 2013 tingkat kesadaran masyarakat akan kesehatan hanya 20 persen. Hal ini berdampak pada menurunnya tingkat kesehatan masyarakat Indonesia. Masyarakat Indonesia umumnya mengonsumsi nasi putih, namun pola konsumsi nasi di Indonesia masih tidak terkontrol dengan baik.

\section{Bawang dayak (Eleutherine}

palmifolia Merr)yang termasuk familia Iridaceae dan bagian yang digunakan adalah umbinya. Tanaman ini sudah digunakan secara turun-temurun oleh masyarakat sebagai tanaman obat karena mengandung senyawa metabolit sekunder yakni alkaloid, glikosida, flavonoid, fenolik, steroid dan tanin yang merupakan sumber biofarmaka berpotensial untuk dikembangakan sebagai tanaman obar modern dalam kehidupan manusia (Galingging,2010;Raga,2012).

Dari fenomena potensi tanaman bawang dayak dan besarnya kontribusi sektor kuliner terhadap perekonomian nasional, maka lahirlah ide untuk mengembangkan usaha Neng Daysi ini menjadi kompetitif dalam menghadapi kompetitor. Peneliti memilih Neng Daysi karena mudah mendapat informasi tentang Neng Daysi, membantu pemilik mewujudkan ekseptasinya. Tentu diperlukan strategi bisnis yang tepat untuk lebih baik dari pesaing Neng Daysi. Produk yang bagus tanpa didukung model bisnis yang tepat akan mengalami kesulitan untuk menjadi bisnis berkelanjutan. tidak hanya untuk produk baru saja, produk yang sudah ada dipasar tetap perlu mengevaluasi model bisnisnya secara berkala.

Menurut Zott et al $(2011)$
menyatakan bahwa model bisnis
menggambarkan isi, struktur dan tata
kelola dari transaksi yang sudah dirancang
untuk menciptakan nilai melalui


eksploitasi peluang bisnis. Osterwalder et al (2005) mendefinisikan model bisnis sebagai alasan bagaimana organisasi menciptakan, memberikan, dan menangkap nilai. Salah satu model bisnis yang paling sering digunakan saat ini dalam merancang model bisnis untuk lanskap bisnis yang berubah secara dinamis adalah dengan menggunakan model bisnis kanvas. Model bisnis kanvas dapat mengkaji seluruh elemen bisnis suatu perusahaan dan menyesuaikan setiap elemen model bisnis dengan cepat ketika terjadi suatu perubahan dalam dunia bisnis.

\section{Identifikasi Masalah}

Bagaimana model bisnis Neng Daysi dengan menggunakan Kanvas Model Bisnis

\section{Landasan Teori}

Definisi dan Elemen-elemen Business Model Canvas (BMC)

Model bisnis kanvas merupakan alat bantu yang efektif, sederhana, dan teruji untuk memahami, memperbaiki, dan menerapkan model bisnis yang sudah ada atau membuat model baru (Osterwalder and Pigneur 2010). Berikut merupakan 9 blok atau elemen dari model bisnis kanvas dan masing-masing memiliki makna dan peran tersendiri (Osterwalder and Pigneur 2010).

1) Customer Segments
Model bisnis dapat menggambarkan satu atau beberapa customer segments, besar atau kecil. Suatu perusahaan harus memutuskan segmen mana yang dilayani dan segmen mana yang diabaikan.

\section{2) Value Proposition:}

Menggambarkan gabungan antara produk dan layanan yang menciptakan nilai untuk customer segments secara spesifik.

\section{3) Channels}

Menggambarkan bagaimana sebuah perusahaan berkomunikasi dengan segmen pelanggannya dan menjangkau mereka untuk memberikan value proposition yang dimiliki.

\section{4) Customer Relationship}

Menggambarkan berbagai jenis hubungan yang dibangun perusahaan bersama customer segments yang spesifik.

\section{5) Revenue Stream}

Menggambarkan uang tunai yang dihasilkan perusahaan dari masing-masing customer segments.

\section{6) Key Resource}

Menggambarkan aset-aset terpenting yang diperlukan agar sebuah model bisnis dapat berfungsi.

\section{7) Key Activities}

Menggambarkan hal-hal terpenting yang harus dilakukan perusahaan agar model bisnisnya dapat bekerja.

8) Key Partnership 
Menggambarkan jaringan pemasok dan mitra yang membuat model bisnis dapat bekerja.

9) Cost Structure

Menggambarkan semua biaya yang dikeluarkan untuk mengoperasikan model bisnis. Ketika model bisnis berjalan maka semuanya memerlukan biaya..

\section{METODE PENELITIAN}

\section{Desain dan Teknik Penelitian}

Desain penelitian yang digunakan ialah metode kualitatif. Input data kualitatif berdasarkan dengan persepsi manusia atau responden. Teknik penelitian studi kasus.

\section{Teknik Pengumpulan Data}

Teknik pengumpulan data yang dilakukan dalam penelitian ini terdiri dari lima teknik, yaitu sebagai berikut:

1. Wawancara (interview)

2. Mendalam (Angket)

3. Observasi

4. Business Model Canvas dan Value Proposition Canvas. Kanvas tersebut dibutuhkan untuk mendesain model bisnis dalam usaha rintisan produk Neng Daysi

5. Dokumentasi

\section{PEMBAHASAN}

\section{Profil Bisnis}

DaysiFarm merupakan bisnis Startup yang beridiri pada bulan april 2018 yang bermula dari pendanaan PKM kewirausahaan Ristekdikti 2018, seiring berjalannya bisnis terjadi pergeseran bisnis menjadi sosial bisnis yang berfokus pada peningkatan kesejahteraan petani melalui budidaya tanaman bawang dayak disekitar kota Subang dan Jatinangor.

DaysiFarm yang telah tergabung kedalam komunitas sosial bisnis Universitas Padjadjaran sehingga mendapat dukungan dari berbagai pihak melalui fasilitas berupa riset, jejaring dan pengembangan produk dengan tujuan meningkatkan kualitas kesehatan masyarakat melalui perbaikan pola konsumsi makanan dan juga meningkatkan nilai jual komuditas bawang dayak yang merupakan tanaman khas Kalimantan. DaysiFarm memiliki produk inovasi pangan fungsional yang terbuat dari bahan baku tanaman bawang dayak.

Neng Daysi merupakan sebuah produk beras herbal instan yang telah diolah bersamaan dengan ekstrak tanaman bawang dayak dan disertai pouch atau kantung yang berisi rempah. Produk Neng Daysi memiliki keunggulan utama pada kepraktisan dan manfaat dari herbal tanaman bawang dayak dan rempah lainnya. hal ini menjadi kekhasan 
tersendiri di tengah banyaknya inovasi pangan instan dipasaran. tatanan keilmuan bisnis ini termasuk kedalam bisnis berbasis kesehatan dan pengolahan sumberdaya hayati menjadi produk turunannya yang bernilai tinggi dengan proses pembuatan menggunakan teknologi tinggi yaitu proses instanisasi nasi.

Penentuan sebuah tim dalam menjalankan bisnis sangatlah penting agar suatu usaha dapat berjalan dengan lancar untuk mengembangkan bisnis diperlukan kemampuan yang baik serta memiliki karakter dalam setiap individu dalam tim tersebut. Penentuan tim dalam mengembangkan bisnis ini meliputi CEO, CTO, CFO, CMO, dan manager. Dalam setiap tim pada bisnis ini memiliki fungsi beserta tugasanya masing-masing yaitu:

1. CEO (Chief Executif Officer) adalah pejabat eksekutif tertinggi di perusahaan yang bertanggung jawab dalam perencanaan, pengelolaan, menganalisis dan mengevaluasi kegiatan usaha sehingga tujuan perusahaan dapat tercapai secara efektif dan efisien.

2. CTO (Chief Technical Officer) adalah sebagai posisi yang penting kedua atau ketiga khususnya di perusahaan berbasis teknologi dan bertanggung jawab dalam proses produksi sampai pengujian produk sesuai dengan yang telah ditetapkan dan mengelola pengembangan produk serta bertanggungjawab langsung kepada pimpinan perusahaan.

3. CFO (Chief Financial Officer) adalah seorang bendahara dalam perusahaan yang bertanggungjawab dalam membuat anggaran belanja perusahaan mulai dari bahan baku sampai dengan distribusi produk serta pembayaran lainnya. Selain itu bertanggungjawab terhadap laporan pengeluaran dan pemasukan kas perusahaan serta gaji karyawan.

4. CMO (Chief Marketing Officer) adalah orang yang bertanggungjawab dalam kegiatan pemasaran dalam sebuah perusahaan yang dapat bertanggungjawab dalam pengembangan strategi dan riset pasar untuk mendapatkan pencapaian yang tinggi dalam proses pemasaran serta memberikan penyampaian nilai produk dan perusahaan kepada pihak lain.

5. Manager adalah orang yang mengatur dan juga memastikan seluruh operasional berjalan lancar dan bertanggungjawab dalam mengatur berjalannya produksi hingga distribusi serta mengawasi kinerja para karyawan di dalam atau diluar perusahaan. 


\section{Busines Model Canvas}

Daysi dengan menggunakan media

Pengembangan strategi yang selama Business Model Canvas adalah sebagai berikut:

ini diimplementasikan oleh bisnis Neng

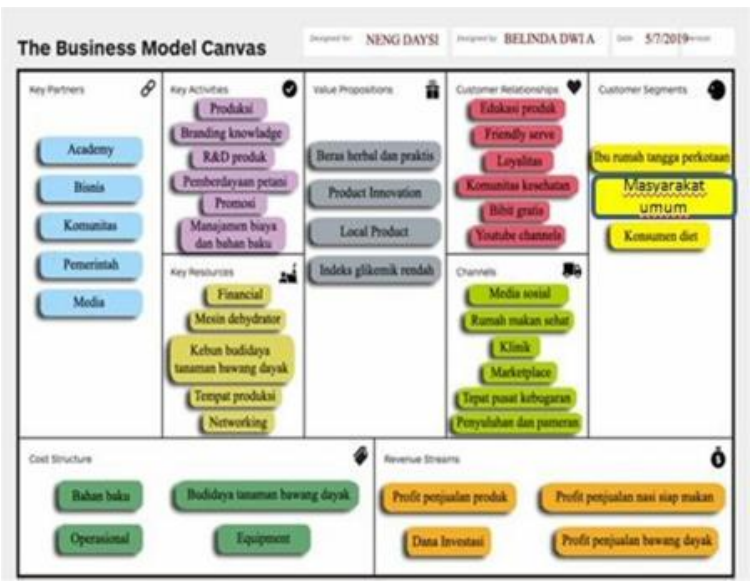

Gambar 1. Business Model Canvas

\section{Value propotion}

Nilai produk yang ditawarkan oleh bisnis Neng Daysi berdasarkan hasil penelitian adalah sebagai berikut:

a) Beras herbal dan praktis

Produk Neng Daysi merupakan produk beras herbal yang mengkombinasikan tanaman bawang dayak dan beras melalui proses instanisasi sehingga produk Neng Daysi selain menyehatkan juga praktis dalam penyajiannya. Beras sehat yang dimaksud adalah beras yang baik untuk program diet karena kandungan kalori yang rendah dan juga kandungan tanaman bawang dayak yang memiliki zat antidiabetes.

b) Innovation product

Produk Neng Daysi merupakan sebuah produk inovasi yang pertama kalinya ada dipasaran karena terbuat dari bahan-bahan tanaman herbal sehingga lebih aman dan tidak memiliki efek samping untuk jangka panjang.

\section{c) Local product}

Lokal pada nilai proporsi dari produk Neng Daysi adalah penggunaan bahan baku lokal yaitu bahan-bahan yang di produksi dalam negeri. Penggunaan bahan baku lokal juga bertujuan untuk memajukan petani bawang

d) Indeks glikemik rendah

Produk Neng daysi memiliki keunggulan dibandingkan dengan beras pada umumnya dimana mengandung indeks glikemik rendah 
atau kandungan akan gula rendah sehingga baik untuk pencegahan diabetes.

\section{Customer segments}

Segmentasi konsumen yang ditentukan oleh produk Neng Daysi menjadi fokus utama dalam bisnis. Berikut hasil penelitian yang telah dilakukan.

a) Ibu rumah tangga perkotaan

Ibu rumah tangga perkotaan menjadi target konsumen produk Neng Daysi karena umumnya sudah menyadari akan pentingnya kesehatan melalui berbagai informasi, dan juga ibu rumah tangga merupakan anggota keluarga yang berperan penting didalam keluarga. Selain itu saat ini aktivitas kegiatan setiap orang sangat cepat, aktivitas yang padat tersebut apabila tidak diimbangi dengan kebutuhan akan asupan yang bergizi maka akan mempengaruhi kesehatan tubuh sehingga melalui produk Neng Daysi kebutuhan akan pangan yang sehat dan juga praktis menjadi solusi terhadap kebutuhan masyarakat yang serba cepat saat ini.

b) Masyarakat umum

Masyarakat produk Neng Daysi juga bisa untuk masyarakat umum dimana usia yang dijadikan target utama pasar produk Neng Daysi yaitu usia kisaran 25 sampai 60 tahun karena di usia 25 tahun yang sudah memiliki penghasilan dan usia 60 tahun rata-rata umur masyarakat yang mengidap penyakit diabetes.

c) Konsumen diet

Konsumen diet merupakan konsumen yang sangat berpotensial untuk pasar produk Neng Daysi karena saat ini terdapat banyak wanita yang melakukan program diet agar memiliki tubuh yang ideal.

\section{Channels}

Usaha yang menghubungkan pelanggan melalui komunikasi,distribusi dan saluran penjualan pada bisnis Neng Daysi adalah sebagai berikut:

a) Media Sosial

$$
\text { Menurut pendapat }
$$

Marionsyah, 2015) bahwa media sosial mampu memberikan customer enggagement sehingga perusahaan memiliki kesempatan untuk menjalin interaksi antara brand dengan konsumen melalui media sosial untuk melakukan komunikasi dua arah. Adapun sosial media yang telah dan harus dilakukan oleh Neng Daysi yaitu:

1. Instagram: www. instagram.com/nengdaysi

2. Facebook page : 
www.facebook.com/nengdaysi

3. WhatApp

4. Channel Youtube

Penggunaan media sosial tersebut dapat membantu dalam memperkenalkan produk sekaligus menarik konsumen untuk menggunakan produk Neng Daysi. Penyampaian informasi yang diberikan pada sosial media yang dilakukan dengan menggunakan foto dan caption yang menarik sesuai dengan tema yang sedang berlangsung pada penggunaan media sosial seperti Instagram karena menurut (Goenawan, 2008) pengguna aktif Instagram sudah mencapai angka 150 juta orang sehingga menempati lebih dari $90 \%$ pengguna Instagram berusia kurang dari 45 tahun, dan $68 \%$ dari jumlah pengguna Instagram adalah wanita. Adapun penggunaan media sosial untuk promosi dapat mengurangi biaya (cost structure) karena tidak semua sosial media yang digunakan berbayar.

Selain itu penggunaan Facebook adds membantu dalam pengenalan produk karena terdapat fitur untuk menjual produk di aplikasi Facebook. menurut We are Social dan Hootssuite menunjukkan bahwa Facebook masih mendominasi media sosial yang banyak diakses di seluruh dunia mencapai 2,2 milyar orang (Marlina 2018). Sehingga media sosial Facebook Adds dapat membantu dalam pengenalan dan penjualan produk.

Penggunaan WhatsApp membantu dalam penyampaian produk kepada segmen. dimana saat ini telah banyak berbagai group wanita di WhatsApp yang dapat membantu pengenalan produk Neng Daysi dan juga sebagai media untuk melakukan pelayan customer service. Sehingga dapat meningkatkan loyalitas konsumen terhadap produk. Layanan lain yang dapat digunakan untuk pemesanan maupun dalam penyampaian informasi lainnya dapat melalui Telepon.

b) Rumah makan Sehat

Menurut beberapa pakar kuliner memperkirakan untuk tren makanan yaitu berbasis healty food atau makanan sehat akan semakin populer, di Indonesia sendiri banyak makanan yang di produksi secara alami, dan untuk saat ini telah banyak rumah makan yang menyediakan makanan sehat seperti salah satu contohnya yaitu rumah makan Burgreens Eatry di Jakarta yang memiliki konsep 
rumah makan dengan makanan berbahan organik. sehingga produk Neng Daysi berpotensi dapat menjual produk di berbagai rumah makan sehat tersebut sebagai pangan dasar yaitu nasi.

c) Klinik

Klinik merupakan salah satu tempat yang dapat digunakan untuk memasarkan produk Neng Daysi, dimana rata-rata didalam klinik terdapat apotek yang umumnya menjual obat-obatan namun terdapat juga makanan kesehatan atau obat tradisional. Sehingga produk Neng Daysi dapat menjual di klinik untuk mengenalkan kepada pelanggan yang menginginkan tubuh yang sehat. Selain penjualan produk di klinik penjualan tanaman bawang dayak yang telah diolah dapat dilakukan untuk mengenalkan obat herbal kepada pelangga yang datang ke klinik tersebut.

d) Marketplace (E-market)

Menurut (Kodong, 2012) Emarket sebagai tempat bertemunya penjual dan pembeli secara online yang memiliki manfaat diantaranya sebagai perluasan jaringan dan meningkatkan penjualan khususnya bagi usaha kecil atau mandiri yang bermodal menengah ke bawah ataupun wirausaha baru yang sedang merintis bisnis atau usahanya. E-market tidak terbatas oleh waktu dan kondisi geografis yang dapat diakses dimana dan kapan saja sehingga sangat baik untuk pengenalan dan penjualan produk dalam lingkup yang lebih luas. Penjualan produk Neng Daysi di $E$ market yaitu seperti di Shopee, Tokopedia dan Bukalapak.

e) Tempat Pusat Kebugaran

Menurut (Wijayanti, 2009) Kebugaran menurut KBBI diartikan sebagai hal sehat dan segar atau kesegaran badan. faktor-faktor yang mempengaruhi kebugaran seseorang antara lain adalah daya tahan, kekuatan otot, kecepatan, ketangkasan, kelenturan, keseimbangan, kecepatan reaksi, dan koordinasi antara bagianbagian tubuh sedangkan tujuan akhir dari latihan kebugaran adalah untuk:

1. Keadaan tubuh yang baik secara menyeluruh

2. Pembakaran lemak dan kelangsingan (spinning, aerobik, kebugaran jantung)

3. Pertumbuhan tubuh (hipertrofi) atau bertambah kuatnya otot (binaraga)

Produk Neng Daysi dapat 
dikenalkan di pusat kebugaran karena di tempat tersebut terdapat bayak orang-orang yang menginginkan kesehatan akan tubuh terutama pada wanita karena menginginkan kelangsingan terhadap tubuhnya. sehingga produk Neng Daysi dapat mudah diterima untuk dikonsumsi oleh orang- orang yang ada di pusat kebugaran.

f) Penyuluhan dan Pameran

Kegiatan pameran dilakukan untuk mengedukasi tentang produk Neng Daysi sedangkan pameran dilakukan untuk pemasaran secara offline. Penyuluhan yang dilakukan yaitu sebagai edukasi kepada masyarakat terkait dengan keunggulan produk Neng Daysi dan pentingnya mengubah pola makan agar dapat terhindar dari penyakit diabetes. Penyuluhan dapat dilakukan di sekitar daerah kota Bandung dan kegiatan pameran dapat dilakukan dengan mengikuti berbagai acara pameran makanan yang banyak diadakan di Kota Bandung.

\section{Customer Relationships}

a) Edukasi keunggulan produk

Produk Neng Daysi merupakan produk baru dimana masyarakat belum mengetahui akan produk pangan fungsional yang terdapat didalam produk Neng Daysi, sehingga produk Neng Daysi perlu dilakukan edukasi pengenalan akan produk serta keunggulan yang terdapat didalamnya. Sehingga produk Neng Daysi dapat diterima di masyarakat dengan tujuan untuk meningkatkan penjualan.

b) Friendly Serve

Pelayanan yang diberikan kepada konsumen misalnya dengan memberikan perhatian kepada konsumen setelah mengkonsumsi produk atau pada saat melayani pesanan konsumen. Dimana hal ini didukung dengan pendapat Kertajaya (2005) bahwa pemberian suatu perhatian-perhatian kecil yang ditunjukan pada konsumen dengan tujuan untuk menyentuh emosi pelanggan secara luar biasa.

Pelayanan yang diberikan yaitu dengan adanya pemberian testimonial pelanggan terhadap kepuasan produk sehingga diharapkan muncul rasa akan kepercayaan terhadap produk Neng Daysi bagi konsumen baru.

c) Loyalitas

Menjaga hubungan yang baik dengan konsumen maka dibangunlah loyalitas dan komunikasi secara langsung maupun tidak langsung. 
Pendekatan personal yang dilakukan misalnya dengan pemberian Greetings Card pada saat pembelian produk. Interaksi langsung yang dijalin dengan konsumen melalui costumer service seperti aplikasi chat dan media sosial dimana kegiatan interaksi tersebut dimanfaatkan untuk mengefisiensikan teknologi sehingga dapat terjalin interaksi langsung dengan konsumen.

Adapun interaksi lain yang dilakukan ialah memperhatikan konten media sosial yang akan diunggah, misalnya dengan pemberian Caption atau keterangan pada saat mengunggah foto yang memiliki informasi penting dan mencantumkan value propotion produk sehingga konsumen dapat mengetahui informasi tersebut.

Pendekatan personal yang dilakukan yaitu diharapkan menimbulkan kesan lebih dekat dengan konsuemn sehingga dapat bertukar informasi untuk evaluasi bisnis dalam pemenuhan kebutuhan konsumen. Neng Daysi juga memberikan hadiah pada saat give away untuk membuat hubungan dengan pelanggan supaya memberikan kesan apresiasi kepada pelanggan.

d) Komunitas kesehatan
Membentuk komunitas kesehatan dengan ibu-ibu di perkotaan, hal ini dapat dilakukan dengan pertam-tama mengikuti komunitas yang umumnya di dominasi oleh kegiatan ibu-ibu sehingga dengan demikian dapat terjalinnya ikatan dan seiring berjalannya waktu dapat dibentuk komunitas kesehatan akan pentingnya menjaga pola makan. Sehingga produk dapat dijual dan penyebaran informasi terhadap value propotion pada produk.

e) Bibit gratis

Pelayanan lain yang diberikan yaitu dengan adanya gratis mendapatkan 1 bibit tanaman bawang dayak untuk pembelian 10 pes produk Neng Daysi, dengan bentuk pelayanan ini dapat terus menjalin hubungan baik dengan konsumen dan juga sebagai bentuk pengenalan eksistensi tanaman bawang dayak.

\section{f) Channel Youtube}

Media sosial seperti Youtube saat ini banyak digunakan untuk kepentingan dalam bisnis, sehingga hal ini menjadi peluang untuk bisnis produk Neng Daysi untuk dikenalkan kepada masayarakat. Konten-konten Youtube berisi bagaimana pentingnya menjaga kesehatan untuk dimasa yang akan datang dan diberikan informasi 
akan keunggulan dari tanaman bawang dayak yang menjadi bahan baku utama dalam produk, dengan begitu masyarakat diharapkan tersadarkan dalam menjaga kesehatan untuk mengubah pola makan dengan produk Neng Daysi.

\section{Revenue Stream}

Beberapa cara untuk mendapatkan keuntungan yang didapatkan dari setiap segmen konsumen yaitu dengan penjualan aset, biaya penggunaan, biaya berlangganan, pinjam/penyewa/leasing, dan lisensi (Osterwalder \& Pigneur, 2010). Arus pendapatan yang dilakukan oleh produk Neng Daysi adalah:

a) Profit Penjualan Produk

$$
\text { Bisnis Neng Daysi }
$$

didapatkan dari penjualan produk dan hasil penjualan produk akan diputarkan menjadi modal dan keuntungan untuk bisnis.

b) Profit penjualan nasi siap makan

Pengenalan produk Neng Daysi agar dapat diterima oleh masyarakat yaitu dengan nasi siap makan dari beras Neng Daysi. Nasi siap makan yang terdiri dari nasi Neng Daysi dan penambah makanan lainnya.

c) Profit penjualan tanaman bawang dayak

Pendapatan pada bisnis Neng
Daysi selain dari produk Neng Daysi, Neng Daysi nasi siap makan dan menjual tanaman bawang dayak dalam bentuk segar dan juga menjualnya dengan berbentuk kemasan teh herbal bawang dayak. Cara ini membantu penyampaian informasi terkait produk Neng Daysi kepada masyarakat.

d) Dana Investasi

Dana investasi merupakan langkah awal dalam pengumpulan dana yang dilakukan oleh bisnis Neng Daysi dimana dana investasi didapatkan dari dana awal Ristekdikti yang kemudian dana tersebut dijadikan modal awal untuk usaha ritisan Neng Daysi. Bisnis produk Neng Daysi apabila dilihat dari pertumbuhannya yang semakin menurun disebabkan karena produksi yang terbatas oleh teknologi sehingga memungkinkan bisnis Neng Daysi harus mencari investor untuk mau menanamkan modalnya agar dapat berjalannya bisnis produk Neng Daysi.

\section{Key Activities}

Dalam menjalankan bisnis hal yang terpenting harus dilakukan untuk menjadikan model bisnisnya bekerja dengan bentuk tindakan yang yang dilakukan untuk menciptakan dan menawarkan value proposition, 
menjangkau pasar, mempertahankan customer relationship, dan mendapatkan pendapatan (Osterwalder \& Pigneur, 2010). Kegiatan yang dilakukan oleh Neng Daysi dalam menjalankan bisnisnya adalah sebagai berikut:

a) Produksi

Produksi dilakukan setelah tahap evaluasi berupa informasi dari tahap sebelumnya. proses produksi dilakukan dengan perbaikan-perbaikan yang diperlukan dimana kegiatan produksi terdiri dari persiapan bahan baku, pembuatan nasi instan dan proses pengemasan.

\section{b) Branding Knowladge}

Branding knowladge atau edukasi terhadap keunggulan produk yang tersedia pada value propotion produk Neng Daysi memiliki brand seperti local product, menyehatkan dan praktis. sehingga kegiatan branding bertujuan untuk mengubah pola pikir masyarakat untuk mau mengubah pola makan yang lebih sehat dalam mengkonsumsi nasi melalui produk Neng Daysi yang selain praktis namun tetap menyehatkan dan tidak memiliki efek samping bagi kesehatan. Kegiatan yang dilakukan yaitu dengan mengadakan beberapa kegiatan seperti ikut dalam acara komunitas kesehatan dan mengikuti berbagai pameran. kegiatan ini dapat membantu untuk peningkatan penjualan produk dan mengenalkan keunggulan dari produk Neng Daysi.

c) Research and Development (R\&D)

Kegiatan ini merupakan langkah awal dalam pembuatan produk Neng Daysi dimana langkah awal dilakukan pada kegiatan ideasi dan studi pustaka, ideasi dilakukan untuk memberikan gagasan ide-ide yang akan di perkuat dengan studi literatur sedangkan studi pustaka berlangsung sebelum produk dibuat. Namun studi pustaka ini dilakukan secara terus menerus karena pada saat pembuatan produk selalu terdapat masalah yang nantinya akan dijadikan sebagai bahan evaluasi. adapun solusi dari masalah yang selama pembuatan produk didapatkan dari informasi-informasi yang dikaji pada saat studi pustaka dan diperkuat dengan opini-opini yang ada. selain itu kegiatan studi pustaka dilakukan dengan mengkaji artikel ilmiah dan jurnal untuk memperkuat informasi yang dibutuhkan.

Proses pengembangan produk Neng Daysi dilakukan dengan adanya kegiatan pembuatan sampel yang nantinya akan diuji coba kepada 
panelis untuk selanjutya dapat dievaluasi. umumnya yang diujikan kepada panelis adalah uji organoleptik seperti uji rasa nasi, bau nasi, dan tekstur nasi. Setelah sampel yang telah diuji dan diperikasa dan sudah sesuai formulasi maka akan berlangsung ke dalam tahap berikutnya.

Kegiatan evaluasi dilakukan untuk mengetahui hal apa yang harus diperbaiki untuk meningkatkan kualitas dari produk Neng Daysi dan juga masukan-masukan dari panelis diperhatikan pada saat evalusi sebagai informasi selanjutnya.

d) Pemberdayaan Petani

Pemberdayaan petani dilakukan oleh bisnis produk Neng Daysi yaitu untuk meminimalisir biaya distribusi bahan baku dengan cara memberdayakan petani lokal maka selain menguntungkan bagi bisnis, eksistensi tanaman bawang dayak juga dapat dikenal oleh petani. sehingga terbentuknya hubungan saling menguntungkan antara petani lokal dan perusahaan. Kegiatan pemberdayaan petani meliputi bagaimana cara menanam dan merawat tanaman bawang dayak dengan baik yang tentunya akan menghasilkan kualitas yang baik untuk dijadikan sebagai bahan baku utama pada bisnis produk Neng Daysi.

e) Promosi

Kegiatan promosi merupakan peranan yang penting untuk berjalannya perusahaan start up yang masih belum dikenal oleh pasar, dimana tujuan dari promosi yaitu agar customer segments atau konsumen tersegmentasi mengenal produk dan berniat untuk membeli produk yang dipromosikan. Promosi yang dilakukan pada bisnis produk Neng Daysi yaitu secara langsung melalui kegiatan bazar dan penyebaran informasi dari mulut ke mulut. sedangkan untuk promosi online dilakukan melalui media sosial sehingga akan memudahkan dalam penyampaian informasi terkait produk yang hendak ditawarkan dengan tujuan agar konsumen tertarik untuk membeli produk Neng Daysi sehingga mengakibatkan terjadinya proses jual beli. Selain itu promosi juga dilakukan dengan pemberian 1 bibit tanaman bawang dayak untuk pembelian lebih dari 10 pes produk Neng Daysi melalui offline maupun online.

f) Manajemen biaya dan bahan baku

Pembuatan rencana biaya membantu bisnis dalam 
mengeluarkam biaya bahan baku, biaya produksi, dan biaya pemasaran, berdasarkan hasil penelitian bisnis Neng Daysi memiliki kelemahan dalam anggaran biaya yang belum efektif dan efisisen. Sehingga dengan melakukan rencana biaya secara berkala dapat membatu bisnis untuk lebih baik dalam penggunaan biaya.

Rencana anggaran bahan baku yaitu dengan melakukan kegiatan budidaya tanaman bawang dayak sehingga dapat memudahkan dalam proses perencaanaan produksi, melalui budidaya tanaman bawang dayak selain dapat menekan biaya bahan baku dan distribusi bisnis juga dapat membantu masyarakat sekitar Jatinangor untuk memberdayakan petani dengan menanam tanaman bawang dayak.

\section{Key Resources}

Aset yang paling penting dibutuhkan oleh perusahaan dalam menjalankan model bisnis, dimana sumber daya ini dapat membuat perusahaan untuk menawarkan sesuatu dan menawarkan value propotion, menjangkau pasar, menjaga hubungan dengan konsumen, dan mendapatkan keuntungan. key resources dapat berupa fisik, intelektual, atau financial (Osterwalder \& Pigneur, 2010). Adapun key resources yang dimiliki oleh bisnis Neng Daysi adalah sebagai berikut:

a) Financial

Sumber daya yang memgang peranan sangat penting dalam menjalankan bisnis khusunya pada bidang keuangan karena berperan sebagai pengelola sumber dana perusahan.

b) Mesin Dehydrator (mesin pengering)

Teknologi yang digunakan pada bisnis Neng Daysi yaitu mesin dehydrator yang digunakan dalam membuat beras instan dan sehat. Mesin ini merupakan alat utama dalam bisnis Neng Daysi sehingga menjadi sumber untuk keberlangsungan produksi Neng Daysi. Namun alat ini bisa digunakan oleh bisnis Neng Daysi karena bermitra dengan produksi lainnya di salah satu komunitas bisnis sehingga hal ini membuat biaya produksi tidak dapat digunakan dengan efektif dan efisien. sehingga memungkan bisnis Neng Daysi harus memiliki mesin dehydrator sendiri untuk menunjang kegiatan produksi menjadi lebih baik.

c) Kebun budidaya taaman bawang dayak

Kebun budidaya tanaman bawang 
dayak merupan salah satu sumber daya yang harus dimiliki oleh bisnis Neng Daysi untuk dapat mengefisiensikan biaya bahan baku tanaman bawang dayak.

d) Tempat Produksi

Bisnis Neng Daysi menjalankan produksi belum didukung dengan tempat produkis yang memadai karena saat ini untuk menjalankan produksi bisnis Neng Daysi masih bermitra. Sehingga kedepannya bisnis Neng Daysi perlu memikirkan untuk memiliki tempat produksi sendiri agar kegiatan produksi bisa lebih efektif dan efisien dan juga dengan memiliki tempat produksi sendiri dapat menunjang untuk syarat PIRT produk.

e) Networking

Sumber daya kunci lainnya yaitu pada jaringan bisnis yang dilakukan oleh Neng Daysi, karena keterbatasan yang dimiliki membuat Neng Daysi melakukan banyak jaringan dengan beberapa stakeholder. sehingga bisnis Neng Daysi dapat berjalan hingga saat ini baik dari jaringan yang berkaitan dengan proses bisnis maupun pembelajaran terkait bagaimana menjalankan sebuah usaha start up bagi mahasiswa.

\section{Key Partners}

Jaringan dari supplier dan mitra yang membuat model bisnis bekerja. Aliansi berasal dari luar perusahaan yang dapat mensuplai dan mendukung dalam menciptakan, mengantarkan, dan menangkap nilai perusahaan (Osterwalder $\&$ Pigneur, 2010). Adapun beberapa mitra yang menjadi bagian di bisnis Neng Daysi yaitu:

a) Academy

Bisnis Neng Daysi diawali dengan kompetisi mahasiswa Indonesia di bidang kewirausahaan yang menjadikan bisnis ini bertumbuh dari berbagai bantuan salah satunya di laboratorium untuk pengujian produk sehingga produk dapat bersaing dengan bisnis lainnya.

b) Business

Business yang dimaksud adalah berbagai mitra yang mendukung berjalannya produksi Neng Daysi seperti petani bawang bibit bawang dayak di Subang, ibu-ibu pengolah sekitar Jatinangor, industri kemasan dan influencers.

c) Influencers

celebrity endorser dapat dijadikan mitra untuk memperkenalakan produk Neng Daysi dengan penyampaian nilai produk kepada customer segment, mitra ini dipiih untuk penyampaian 
nilai dan informasi dan memberikan daya tarik serta branding kepada konsumen.

\section{Celebrity endorser}

Merupakan suatu media bagi perusahaan untuk memperkenalkan dan mengkomunikasikan produknya serta menarik konsumen untuk memillih produk tersebut, dimana penggunaan celebrity endorser sebagai influencer di media sosial digunakan karena atribut yang melekat pada dirinya yaitu daya tarik, talenta dan lain sebagainya. (Shimp, 2003).

a) Komunitas

Menurut .prayoga (2015) peranan komunitas dalam suatu bisnis adalah memberikan saran serta masukan dalam pengembangan produk untuk kemajuan bisnis. Komunitas yang berperan dalam berbagi pengetahuan dan keahlian dengan cara berdiskusi satu sama lain.

b) Pemerintah

Pemerintah berperan sangat penting dalam pemberi kesempatan, momenrum serta akses terhadap kebijakan-kebijakan, selain itu pemerintah sering mengadakan acara untuk pengusaha pemula dalam mengenalkan brand serta produknya seperti pameran dan ajang kompetisi lainnya dan juga pemerintah berperan dalam pembiayaan untuk usaha pemula.

c) Media

Media berperan sebagai promotor brand dan memperkenalkan nilai tambah produk Neng Daysi sehingga produk dapat diketahui oleh masyarakat dan juga media digunakan untuk proses jual beli produk secara online.

10. Cost Structure

a) Bahan Baku

$$
\text { Biaya bahan baku }
$$
merupakan biaya yang dikeluarkan terkait dengan biaya bibit tanaman bawang dayak, biaya beras dan biaya rempah-rempah, biaya ini dikeluarkan untuk mendukung bisnis agar dapat berjalan dengan baik.

b) Budidaya tanaman bawang dayak

Biaya budidaya tanaman bawang dayak yang harus dikeluarkan yaitu untuk proses budidaya dan perawatan.

c) Operasional

Biaya operasional adalah biaya yang dikeluarkan untuk mendukung berjalannya bisnis yaitu biaya kegiatan research and development, produksi, gaji karyawan dan pemasaran.

d) Biaya Research and Development

Biaya ini merupakan biaya yang dibutuhkan untuk pengembangan 
produk dengan meneliti mengenai keamanan produk dan kandungan yang terdapat didalam produk, selain biaya research and development digunakan untuk menyempurnakan produk sehingga dapat lebih bersaing dipasaran.

e) Biaya gaji karyawan

Biaya yang diberikan kepada karyawan sebagai upah dari hasil kerja dalam produksi produksi Neng Daysi.

f) Biaya produksi

Biaya yang digunakan untuk membeli bahan baku yang dapat menunjang proses produksi, biaya ini merupakan biaya pokok yang rutin dikeluarkan.

g) Biaya Pemasaran

Biaya yang dikeluarkan untuk bisnis produk Neng Daysi yaitu untuk pemasaran produk dan branding, dimana bisnis Neng Daysi ini memiliki kelemahan dalam pemasaran dan promosi untuk menyampaikan value propotion produk sehingga biaya pemasaran menjadi hal yang penting bagi bisnis rintisan produk Neng Daysi.

h) Equipment

Biaya bahan yang dikeluarkan secara tidak langsung seperti alat yang produksi yang dapat menunjang proses instanisasi produk Neng Daysi seperti

Dehidrator, dan Freezer.

\section{KESIMPULAN}

Berdasarkan hasil penelitian dengan melihat prtofil bisnis Neng Daysi menggunakan Business Model Canvas terlihat bahwa bisnis Neng Daysi memiliki peluang unuk dikembangkan terlihat Value Propotion yang ditawarkan yaitu beras herbal praktis dengan indeks glikemik rendah, lalu Customer Segments yang dituju yaitu ibu rumah tangga perkotaan yang melek akan informasi dan konsumen diet. sedangkan Channels yang digunakan yaitu media sosial, marketplace, rumah makan sehat, klinik, tempat pusat kebugaran, dan penyuluhan serta pameran. Adapun Customer Relationships yang dibangun adalah dengan mengedukasi produk, friendly serve, loyalitas, komunitas kesehatan, bibit gratis dan youtube channels. Untuk Key activities yaitu produksi, branding knowladge, R\&D produk, pemberdayaan petani, promosi dan manajemen biaya dan bahan baku. Sedangkan untuk key Resources yaitu financal, mesin dehydrator, kebun budidaya tanaman bawang dayak, tempat produksi dan networking. Key partners yang dibangun yaitu dengan academy, bisnis, komunitas, pemerintah, dan media. 
Sedangkan untuk Revenue stream yang didapatkan dari bisnis Neng Daysi yaitu profit penjualan produk, dana investasi, profit penjualan nasi siap makan, dan profit penjualan tanaman bawang dayak dan untuk cost structure yang dikeluarkan oleh bisnis Neng Daysi yaitu biaya untuk bahan baku, budidaya tanaman bawang dayak, operasional dan equipment.

\section{DAFTAR PUSTAKA}

Galingging, R. Y. 2007. Bawang Dayak (Eleutherine Falmifolia) Sebagai tanaman obat multifungsi. Warta Penelitian dan pengembangan. Vol. 15, No. 3, Hal: 2-4.
Alexander Osterwalder \& Yves Pigneur. 2012. Business Model Generation.Cetakan ke-12. P enerbit PT Elex Media Komputindo Kelompok Gramedia, Anggota IKAPI. Jakarta.

Badan Pusat Statistik Jawa Barat. 2017.’PDRB Provinsi Jawa Barat atas Dasar Harga Konstan 2010 Menurut Lapangan Usaha(Juta Rupiah),2010-2016.” Melalui https://www.jabar.bps.go.id (diakses pada Januari 2019).

Zott, Christoph, Raphael Amit, and Lorenzo Massa. 2011. "The Business Model: Recent Developments and Future Research." Journal of Management 37(4): $\quad$ 1019-42.Melalui http://jom.sagepub.com.ezproxy.lib erty.edu:2048/content/37/4/10 